\title{
CHAPTER FIFTEEN
}

\section{DRAMATURGY - STAGING PROBLEMS IN VONDEL'S GYSBREGHT VAN AEMSTEL}

\author{
Peter G.F. Eversmann
}

In 1937, shortly before the third centennial of (almost) yearly performances in the city theatre of Amsterdam, Ben Albach concludes his study of the staging tradition of Vondel's Gysbreght van Aemstel with the following words:

Thus, after three ages, the Gijsbreght tradition is still central to the life and aspirations of the Amsterdam theatre. Independent of the theatrical circumstances, and independent of time, each New Year's day the Heer van Aemstel [i.e. Gysbreght] makes his appearance in the Stadsschouwburg before an auditorium filled with Amsterdam families, including (as always) the youngest generation, which at that moment is present for the first time at the celebration that delighted its ancestors and that at one time will be attended by its offspring. [...] Undoubtedly the 'Gijsbreght van Aemstel', being as it is one of the finest expressions of the Dutch language, will sound on the boards for many ages to come. The Gijsbreght tradition is like an old legend that comes to life each year. May 'Gijsbreght van Aemstel', the symbol of Holland's days of glory, forever roam the Municipal Theatre of the Dutch capital city! ${ }^{1}$

It was not to be. In 1968 the final performance of Gysbreght according to the old tradition was staged in the Stadsschouwburg. And although there have been some productions of the play since then (a few of them explicitly attempting to revive the tradition), not all of these were performed at this theatre and one can no longer speak of an annual event. Moreover, a recent commentary in one of the leading national newspapers - De Volkskrant - characterised the drama as 'generally deemed to be unstageable' ${ }^{2}$ So today it is safe to conclude that the play is rapidly disappearing from the collective memory of Amsterdam

\footnotetext{
${ }^{1}$ Albach, Drie eeuwen 'Gijsbreght van Aemstel', p. 132; my translation.

${ }^{2}$ De Volkskrant, 10 March 2010. ('As a play generally deemed to be unstageable, Van Dis eased the text away from yellowed paper and tradition and even rapped a couple of lines of Vondel.')
} 
theatregoers. The older generation might still retain a dim image of the tradition that is so eloquently described by Albach, but for younger audience members the drama is only a famous title from the past. If one is lucky, some attention will have been given to it in high school and in a few very fortunate cases one will even have read the whole play (most likely in an abridged version in which the seventeenth-century language has been reworked into more intelligible modern Dutch) or have seen a (television) recording of an older performance. However, the annual opportunity to experience a live encounter with the characters onstage is now a thing of the past.

The question as to why this tradition that seemed so fiercely established has been broken after 330 years is a complex one that is not easy to answer. No doubt one can point to an amalgam of reasons, including financial ones, a general revolutionary and avant-garde spirit that pervaded the Dutch theatre at the time of the breach (emphasising renewal and doing away with repertory theatre), estrangement of certain features of the play with regard to both content and structure that became more and more alien to society at large (for example, intervening angels as deus ex machina, religious allusions, the portrayal of women, a male hero glorifying war, etc.) and the difficulties of delivering and understanding seventeenth-century poetic language. Furthermore, it can be argued that in this case the tradition itself can be held partly responsible for its cessation. After all the idea was not to bring museum theatre ritualistically staging the play again and again in the same manner but to renew and contemporise the drama each year so that it could be savoured afresh. However, after a certain number of interpretations it becomes harder and harder to come up with yet another one that does not artificially seek to be 'new' and that does not stress credibility. When - in the sense of Carlson - the 'ghosts' of actors interpreting Gijsbreght, ${ }^{3}$ Badeloch and the other characters become too numerous it is only understandable that a certain weariness is experienced. ${ }^{4}$ In this regard one should also notice that the history of the stagings of Gysbreght is not without problematic periods in which the tradition was endangered by continuity lapses for reasons of production or

\footnotetext{
${ }^{3}$ Apart from quotes, I will use Gysbreght to designate the drama and Gijsbreght when referring to the character.

${ }^{4}$ Cf. Carlson, The Haunted Stage. 'Ghosting' refers to the mechanisms by which theatre makers, actors and knowledgeable audience members will bring previous stagings and characterisations to bear upon the reception of new ones - coloring their perceptions and continuously comparing past and present performances.
} 
politics. Conversely there have also been times when the staging was mindlessly repeated year after year, becoming so boring and superfluous that the critics strongly urged that the play be subject to drastic alteration. ${ }^{5}$ In this respect the 'tradition' is characterised by continuous transformations and modifications - changes in interpretation, text, set design, costumes and acting style - that reflect the ever-changing fashions in Dutch theatre history. In a way, then, the question as to how it is possible that the play was adapted to new circumstances time and again enabling the tradition to persist is just as astute and as difficult to answer as the question of why that tradition finally came to an end. However, the present-day situation, in which one is not hampered by an oppressive and in many ways stifling tradition but is also aware that the drama apparently had enough appeal to inspire theatre makers and their audiences for such a long time, has the advantage of allowing one to go back to Vondel's original text and study it with relatively fresh eyes. In the process one should then ask two questions: what are the problems and challenges when producing this play and what are its features that make adaptation possible for a wide diversity of theatrical conventions. In other words, how can it be that the drama has had such a long staging tradition but is now 'generally deemed to be unstageable'? In what follows I will try to answer these questions by concentrating on the structural characteristics and technical demands of Vondel's text. After all, these internal features of a dramatic text ultimately determine whether it can be adapted to changes in circumstances of production or - within the confines of a specific theatrical paradigm whether it is regarded as principally unfit for staging.

I am consciously leaving aside matters of conceptual interpretation, of intertextual comprehensibility and of how the content of the drama can express present-day concerns or might be updated to appeal to a modern-day audience. Of course, these are important dramaturgical questions that should be answered by theatre makers before they decide to stage Gysbreght. However, these questions primarily pertain to content and to the reasons - the inner need so to speak - for producing the play. As such they are not concerned with the principal question of whether or not a drama is stageable, but rather they belong to the realms of artistic reflection, inspiration and justification. Besides, the existing literature that is addressing these interpretational and

\footnotetext{
${ }^{5}$ See Albach, Drie eeuwen 'Gijsbreght van Aemstel', passim.
} 
contextual matters is quite abundant and enables theatre makers to form a rather clear picture of what Vondel's text means, what certain passages are alluding to and where ostensibly there is room for disagreement among scholars. The secondary literature in the 'Digitale Bibliotheek voor de Nederlandse Letteren' ('Digital Library for Dutch Literature') is a good starting point, and a very recent publication that extensively explores Vondel's inspirational sources and the intertextual aspects of Gysbreght is provided by Marco Prandoni's doctoral thesis Een mozaïek van stemmen: Verbeeldend lezen in Vondels 'Gysbreght van Aemstel' (A Mosaic of Voices: Representational Reading in Vondel's 'Gysbreght van Aemstel'). ${ }^{6}$ However, what I would like to do here is different from these predominantly philological approaches. My aim is to read Vondel's text ${ }^{7}$ from a directorial perspective and to explore its demands and challenges when staging the play. In other words, what are the immanent clues that one should consider when trying to give form to this text in a three-dimensional, multimedial and time-based event? It goes without saying that this is a virtual exercise and that one should not necessarily adhere to these clues in an actual production process. It is quite possible to ignore them or to express them onstage in such a way that the presentation supplements, contradicts or ironically comments upon the text. When, for example, Gijsbreght asks for his sword ('T'sa dienaers schaft geweer' [883]) it may very well be the case that in one particular production his servants will hand him an automatic rifle, while in another one he will be presented with a paintball gun or a children's toy sword. Furthermore, in this virtual exercise I will proceed from the assumption that the full text and the order of its scenes are adhered to and that, apart from translating the seventeenthcentury language into a contemporary Dutch idiom, the source material is not being adapted into a principally different play. Of course,

\footnotetext{
${ }^{6}$ DBNL, see http://www.dbnl.org/titels/titel.php?id=vond001gysb01; Prandoni, M., Een mozaïek van stemmen.

7 I will use the text of the first edition (t'Amsterdam. By Wilhelm Blaeu. 1637) as it is found in the DBNL: Vondel, WB 3, pp. 514, 523-600. This text includes Voorwerk (the dedication to Hugo Grotius), Voorspel (address to 'Schout, Burghemeesters, Schepens en Raed van Amsterdam'), Op den nieuwen Schouwburg (address to the 'Raedsheer Nikolaes van Kampen'), Kort Begrijp (abstract of the story) and Spreeckende Personagien - Stomme (the list of characters) and Gysbreght van Aemstel. Treurspel (the full text of the tragedy). When referring to specific lines, I will use the numbering as given by the DBNL in brackets - for the paratext with designation (e.g. Voorwerk, ll. 55-59) and for the full text of the drama without (e.g. 1l. 16-17). The translations of the Gysbreght are taken from the one made by Kristiaan Aercke.
} 
this is not particularly realistic and probably the first thing a director would do nowadays is omit lines or even whole scenes, reorder the text and maybe insert other texts into the performance, ${ }^{8}$ but this would only attest to the opinion that (part of) the subject matter of the play is indeed unstageable - either because a modern-day audience would lack the frame of reference needed to interpret certain phrases or because one feels an artistic need to change the content of Vondel's drama.

In addition, it is not my intention to reconstruct the original performance of 1638 as it was staged in the then newly erected Schouwburg. Several attempts to effect such a reconstruction have been put forward but it is my conviction that, although very worthwhile suggestions have been made on how the polytopic stage might have been used, the historic information is not sufficient to give a full-scale and detailed account of what the first production looked like and how the mise en scène was executed. However, I will occasionally refer to the historical evidence and the original production circumstances insofar as they have been documented because they can complement Vondel's text by providing information on the theatrical conventions for which it was written. It is these conventions that will at times highlight staging problems posed by the text and that will also enable us to appreciate how, in other times and with other theatrical conventions, different solutions had to be found. To cite an obvious example, in 1638 all parts were performed by men and this could have had direct consequences for the number of actors involved since in principle the doubling of male and female parts was possible. But in times when the cross-gender casting of female parts is no longer en vogue, this is clearly impossible, resulting in a larger cast.

Speaking of theatrical conventions it is interesting to note that Vondel himself remarks in the dedication of the drama to Hugo Grotius that - although he has taken certain poetic liberties - the work, as far as he is aware, does adhere to the laws of the stage, with the possibility of one exception: the large number of characters that ensues from 'the requirements of the work' (i.e. the nature of the story itself). He writes:

We decorated and furnished the same according to the laws, rules and liberties of poetry, and according to the laws of drama. If we violated the

8 This is precisely what Margrith Vrenegoor did when staging the drama in 1995. Cf. Deuss, 'De Gijsbrecht in 1995'. 
latter it was not on purpose, save, perhaps, for the large number of characters (which we could scarcely avoid without depriving the work of what it requires). ${ }^{9}$

Indeed, it seems that Gysbreght requires quite a number of actors. The list of speaking characters consists of sixteen roles and one trumpeter. Besides these there are groups of characters indicated. These comprise four reyen (Amsterdamsche Maeghden, Edelingen, Klaerissen and Burghzaten, i.e. Virgins of Amsterdam, Noblemen, Clares and Denizens) and three other groups (hoplieden, bondtgenooten and vlughtelingen, i.e. captains, allies and refugees). On top of this there are also non-speaking characters. These comprise three groups (Katuizer, Egmonds soldaten and Gijsbreght van Aemstels dienaers, i.e. monks of the Carthusian convent, soldiers to Egmond and servants to Gijsbrecht) and one single role, the bastard son to Count Floris Witte van Haemstee. Even if one assumes a doubling of roles for the reyen and the other speaking groups and allows for only two persons per group this means that at least eleven more persons are needed, bringing the total to twenty-seven. It might be possible to reduce this number a little bit by doubling some of the speaking roles (Willebord and Raphael, Vosmeer and Heer van Vooren, Willem van Egmont and the messenger, Diedrick van Haerlem and Broer Peter), but still the cast would be quite large and the evidence from the seventeenth century strongly suggests that such doubling was not at all customary. Instead, one would assume the number of players to be even higher because two persons for all the reyen seems too low. Albach notes that in 1641 four singers were engaged for these sung parts - accompanied by three musicians - and he gives a total of thirty players (24 speaking actors and 6 'Piekeniers', or pikemen) for the production in $1658 .{ }^{10}$ All in all one should conclude that an unabridged and unadapted version of Gysbreght would require a rather large cast and is therefore relatively expensive to produce - certainly if one also opts for a lavish set and elaborate costumes. This conclusion is more or less corroborated by the expenses of the first 13 performances in 1638: 1363 guilders-15 five-cent pieces-12 cents; quite a large sum indeed, but the income (2459 guilders-18 cents)

9 Dedication, 1l. 55-59: '[...] en stoffeerden en bekleedden de zaeck na de wetten, regelen en vrijheid der poëzije; oock na de tooneelwetten, waer tegens wij wetende niet en misdeden, 't en waer misschien in talrijckheid van personagien, dat wij qualijck konden vermijden, zonder het werck zijnen eisch te weigeren.'

${ }_{10}$ Albach, Drie eeuwen 'Gijsbreght van Aemstel', p. 20 en pp. 142-43. 
shows a tidy profit. ${ }^{11}$ Let us now have a further look at the what the text of Gysbreght suggests for its realisation onstage in terms of setting, time, reyen, costumes and props and the action of the drama.

\section{Spatial Configuration}

First of all then it should be noted that there is almost no secondary text - no prescriptions of what the stage or costumes should look like, no explicit indications by the author on the behaviour of the characters or on their physical appearance. The only indications that are given are the headings of the acts and the names of the characters that speak. This is not to say that there are no clues whatsoever as to what can be perceived onstage, but almost all these clues are immanent in the clauses of the characters and have to be deduced by careful analysis. This is, of course, in line with other plays from the period, but it is good to realise that it is precisely this lack of prescriptive descriptions and staging indications that provides a lot of freedom for theatre makers. In terms of clues for the setting, the relative indefiniteness as to where the action takes place becomes particularly apparent. As justification for adhering to the norm of the unity of place Vondel writes that 'the play takes place in front of and in the city and in the castle' ('het tooneel is voor en in de stad en op het huis' (Kort Begrijp, 1. 48), but the indications in the text are a little bit more specific. The first and second acts are indeed set outside the walls of the city. In Gijsbreght's soliloquy at the beginning of the play he describes the surroundings thus: 'Here their troops encamped; littered is the entire field / With arms and gear.' ('Alhier, daer 't leger lagh, is 't veld alsins bezaeit / Met wapens en geweer', 11. 16-17). Later on it becomes clear that this place is probably not far from the Carthusian monastery, ${ }^{12}$ that one can discern a ship loaded with firewood from here ${ }^{13}$ and that one of the gates of the city is nearby. ${ }^{14}$ From these clues and the fact that Arend appears on the scene

\footnotetext{
${ }^{11}$ Ibidem, p. 138.

${ }_{12}$ Vondel, Gysbreght, ll. 158-59: 'Maer 'k zie den vader daer van ons Katuizers klooster genaecken van ter zy [...]'

${ }^{13}$ Gysbreght, 1. 378: 'Ghy ziet hoe daer een schip, het Zeepaerd, leit, vol rijs.'

${ }_{14}$ This can be inferred from Vosmeer's lines '[...] ' $\mathrm{k}$ wil liever voor uw poort, [...] dit lastigh leven laeten' (1l. 402-03) and from the invitation of the Rey van Amsterdamsche maeghden to enter the city: 'Treck in, o Aemstel, treck nu binnen, [...] treck in o braeve burgery' (1l. 445-48).
} 
after having pursued the enemy along the 'Haerelemmer dijck' ('the Haarlem dike, 1. 8) it has been rightly concluded that the first act is set in front of the Haarlemmer Poort, at the northwest corner of the city. At the same time one should realise that the old Amsterdam, in which Gysbreght is set, is not a historically accurate reconstruction of the situation 300 years before Vondel's time. Rather, both the old and the new Amsterdam form an imaginary amalgam that is based on older maps of the city coupled with the wish to present recognisable features of seventeenth-century Amsterdam for the contemporary audience. ${ }^{15}$ At any rate, one cannot maintain that the locations as portrayed in the drama describe definite settings to which theatre makers should adhere. Instead, one is faced here with a kind of word scener $y^{16}$ in which the text leaves room for a lot of imagination. Thus the stage can be designed in an elaborate and detailed way, but at the same time it is possible to have a more neutral setting in which in their mind's eye the theatregoers complement the structural elements of the stage with the textual indications provided by the characters. And this general principle applies not only to the location of the the first act but for the indications pertaining to the rest of the settings as well. The second act also takes place outside the city walls, near the Carthusian monastery and at its gate, ${ }^{17}$ but also at another, less distinct place near the city and a waterway leading into it. ${ }^{18}$

Together, then, the first two acts take place outside the city and one can envision them well on a polytopic stage where (for example) the city gate is located in a central part, the Carthusian monastery is to the right side of the stage and Vosmeer and Egmont meet somewhere on the left. As such this scheme would probably fit well on the stage of the new Schouwburg, but other solutions are possible as well ${ }^{19}$ and we

\footnotetext{
${ }^{15}$ See the discussion by Smits-Veldt in Vondel, Gysbreght van Aemstel, ed. SmitsVeldt, pp. 11-12.

16 Pfister, The Theory and Analysis of Drama (tr. Halliday), p. 267. Often such 'spoken space' has the function to compensate for restricted means in scenic presentation and this might very well be the case with Gysbreght. The interesting feature here is that the spaces are not described in extenso but depend largely on the knowledge of the spectators who can activate their familiarity with certain locations when hearing their names.

17 'Wy zijn by 't klooster weer' (1. 451); 't Katuizers klooster is ons 't reedst, het leit hier by' (1. 491); 'wie klopt'er?' (1. 503).

${ }_{18}$ Gysbreght, 11. 498-99: 'Ick gae terwijl na stad, om Vosmeer noch te spreecken, Die ter gezette tijd koomt zwemmen door den boom.'

${ }_{19}$ See (for example) Hummelen, Inrichting en gebruik van het toneel in de Amsterdamse schouwburg. pp. 44-45.
} 
cannot be sure of the original mise en scène. In the third act the scene shifts to inside the castle. Not much more can be deduced from the text than that Gijsbreght shortly leaves the scene in order to assess what the situation with the surprise attack is from the parapet of one of the towers. ${ }^{20}$ Whether or not we actually see Gijsbreght sprinting up a flight of stairs and - not long after - see him deliver the lines in which he describes how the taking of the town is proceeding (ll. 874-83) ${ }^{21}$ from a lofty vantage, is something that again is up to the theatre maker. In 1638 the new theatre with its permanent stage building that provided balustrade balconies on either side of the 'heavens' certainly did offer possibilities for such a mise en scène, but whether or not these possibilities were actually used is pure conjecture.

The fourth act starts inside the church of the Klaerissen nunnery. Not much more is said of this place than that there is an altar and a cross, a chair for Gozewijn to sit in, possibly chorister benches for the nuns and, nearby the altar, an alabaster tomb of a martyr. ${ }^{22}$ This part ends with Gijsbreght leaving the scene by going upstairs ${ }^{23}$ again and certainly in later productions but most probably also in $1638^{24}$ - with a pantomime and a tableau of the murder of the nuns (see below). The rest of the act and the initial scenes of the fifth one - until the end of the messenger's story when Gijsbreght and Arend leave to make a sally (l. $1520)$ - are situated inside the castle, most likely in a room. What happens afterwards is a little unclear, but most probably the scene shifts to another location within the grounds of the castle, either the courtyard

\footnotetext{
20 'Ick zal terstond om hoogh gaen zien van Schreiers toren' (1. 851).

${ }^{21}$ These lines are almost a teichoscopy (i.e. a character on stage describes spatially hidden action that takes place simultaneously) but different in so far as Gijsbreght describes what he hears and just saw (past tense!) and not what he sees. For an exploration into the nature, functions and effects of teichoscopies and messenger stories see Eversmann, 'I Saw It with My Own Eyes'.

${ }_{22}$ 'This altar is our refuge' ('dit outer is ons wijck', 1. 977); 'before this altar' ('voor dit autaer', 1. 988); 'Now children, sit down here, ...' ('Nu kinders zet u hier, ..., l. 1005) and later - in Act V - in the descriptions of the messenger (ll. 1393-1520, specifically 1418, 1457 and 1493-96). Smits-Veldt, '3 Januari 1638. Opening van de Amsterdamse Schouwburg met Vondels Gysbreght van Aemstel', p. 207, assumes that the candle mentioned in the Schouwburg ledger in 1637 was placed on the altar.

${ }_{23}$ 'Hold, the enemy is here, I must be off now' ('Daer is de vyand zelf, ick vliegh na boven toe', 1. 1070).

${ }_{24}$ This is concluded by Albach, Drie eeuwen 'Gijsbreght van Aemstel', p. 22 from the fact that Witte van Haemstee, who commits the murder, is specifically mentioned in the list of non-speaking characters and from visual as well as descriptive evidence of 18th-century productions.
} 
or in front of the gate with the bridge over the castle moat. ${ }^{25}$ We can infer this from Badeloch's teichoscopy (1l. 1521-27), which describes how the garrison falls back and is demolishing the bridge while Gijsbreght goes back to search for his brother. Furthermore, this episode of the sally might have been enacted onstage in a pantomime that would have served to bridge the apparent time gap between 1l. 1520 and 1521. At any rate, at the behest of Gijsbreght to carry the dead in ('men draegh den doode binnen', 1. 1550) it becomes clear from his entrance with the dying Arend that the action is set in an outside location. There might be a shift in focus for the negotiations with the Heer van Vooren but apparently the scene remains outside, near the moat ('We stand before this moat, ready to attack', 'Wy staen voor deze graft tot storremen gereed', 1. 1552), so that one does not necessarily need a change of place or scenery here. After this scene Gijsbreght is reunited with Badeloch, their children, Broer Peter and the refugees, something that can be deduced from the fact that he has to inform them about his dealings with the enemy ('I think we gave Vooren a brief and clear reply', 'Wy gaven Vooren kort en duidelijck bescheed', 1. 1655), so most likely this takes place indoors in a place to which Arend's body has been carried. ${ }^{26}$ At any rate, from this moment on until the end of the play with the appearance of the angel Raphael there is no more change in location. One may assume once more that the polytopic stage of 1638 could well have been used to present the different castle locations needed in Acts IV and V - the inside room, the courtyard or a place near the gate and maybe even a somewhat higher location on the parapets which could have been used for Badeloch's teichoscopy and possibly also for the negotiations with the Heer van Vooren - but again there is a complete lack of clues as to the actual staging.

\section{Temporal Configuration}

A similar analysis is possible with the time that is portrayed in Gysbreght. It was noted earlier that the action took place some three

${ }^{25}$ There is also, however, a theoretical possibility that this shift is unnecessary; one has to assume, then, that the previous scenes with Badeloch and Arend (Act IV), as well as the scenes featuring the return of Gijsbreght and the messenger (Act V) are taking place outside - in the castle's courtyard.

${ }_{26}$ This indoor location fits with 'All the people leave first, then the body' ('Al 't volck ga voor, dan 't lijck', l. 1877) and also with Gijsbreght giving the cross he has inherited 
hundred years before Vondel's time - as he himself writes: 'Three hundred years our stage will now leap back' ('Het nieuw tooneel drie eeuwen springt te rugh, Voorspel, 1. 13). In accordance with the unity of time Vondel gives precise directions as to the beginning and end of the drama: the time represented spans a period commencing at three oclock in the afternoon on Christmas Eve and drawing to a close during the early dawn of the following day. ${ }^{27}$ Although it is a little harder to give exact times for each of the different acts and scenes, it is nevertheless possible to follow the timing of the portrayed events rather well. After Act I there is obviously a time leap because Act II begins in the evening after the Carthusian monastery has already closed its gate ('It's pitch dark; we don't really care for friends right now', 't is avond, en een tijd daer ons geen vriendschap dient', 1. 504, and 'We never open / This late,' 'Men opent hier geen deuren / Zoo spade', 11. 506-07). Later on in the act Egmont meets Vosmeer in the dark (1.609) and the act ends with the 'Rey van edelingen' ('Chorus of Noblemen') going to the mass at midnight (1l. 675-76). Act III picks up a little later with Badeloch recounting that she has slept past the time to go to church: 'But look, I overslept. / I will be late for church' ('ick heb mijn uur verslaepen, / Om na de kerck te gaen', 1l. 825-26). In addition, it is said that the attack has taken place when all the citizens have gone to church to celebrate Christmas (11. 844-45) - so just after midnight. The further scenes do not contain clear clues as to when exactly they take place, but working back from the indication 'dawn' (somewhere between 7 and 8 a.m.) for the last scene it is not too hard to give approximations for when the various events onstage and offstage are supposedly taking place. However, besides the utterances of the characters, there is no need to designate further the times of day or night with the help of other theatrical sign systems or to strive for realism with (for example) the lighting conditions. On the contrary, even, if one were to try and fully emulate onstage Vosmeer's 'it is dark' (1. 609), the ensuing conversation with Egmont would probably be lost on most of the audience. At the same time, however, it will be clear that the scene would lose its

from his forefathers to Broer Peter (1. 1879) since it is unlikely that he would have this to hand outdoors.

${ }_{27}$ Cf. 'Ter middernacht, zijnde kersnacht, eer de maen op' (Kort begrijp, 11. 14-15) and 'Het treurspel begint na middagh ten drie uuren en eindigt in den morgenstond' (Kort begrijp, 1l. 50-51). 
credibility when performed in a much brighter light than the preceding scene. In 1638 this probably would not have been of much concern, but a modern day performance with the extensive lighting techniques that are now available should certainly take such details into consideration.

\section{Reyen - Choruses}

In the above analyses of time and space as portrayed in Gysbreght, not much attention has been given to the reyen - the seventeenth-century equivalent of the chorus in ancient tragedies - that form a characteristic structural element of Gysbreght and pose particular problems for staging the play; both in terms of delivery and mise en scène as well as in terms of content. There are four such reyen:

Table 1: The reyen in Gysbreght

\begin{tabular}{lll}
\hline Act/verses & Rey (Chorus) & Content \\
\hline I [415-50] & $\begin{array}{l}\text { Rey van Amsterdamsche } \\
\text { maeghden }\end{array}$ & $\begin{array}{l}\text { Song of praise for the } \\
\text { liberation of } \\
\text { Amsterdam; invitation } \\
\text { to rejoice both at the end } \\
\text { of the hostilities and at } \\
\text { Christmas. }\end{array}$ \\
& Rey van edelingen & $\begin{array}{l}\text { Song of praise for the } \\
\text { Christ child: at once } \\
\text { divine ruler and humble } \\
\text { child. }\end{array}$ \\
& Rey van Klaerissen & $\begin{array}{l}\text { Lamentation on the } \\
\text { massacre of the }\end{array}$ \\
III [903-50] & Rey van burghzaten & $\begin{array}{l}\text { Innocents in Bethlehem. } \\
\text { Song of praise for the } \\
\text { love between Gijsbreght } \\
\text { and Badeloch; pity for } \\
\text { the latter who fears her } \\
\text { husband to be dead. }\end{array}$ \\
& &
\end{tabular}


The structural function of these reyen is clear: they demarcate the end of an act and lead on to the next one. ${ }^{28}$ As such they stand apart from the continuum of the story, even though their names indicate groups of Amsterdam citizens that might be said to play a role in the narrative. In the case of the third one the members of the rey actually do have such a supplementary role and function as characters in the act that follows. However, these choral episodes are not on the same par as the rest of the scenes; the metre of the verses is different and we know that in Vondel's time the stanzas were sung to the accompaniment of musicians - probably by two singers taking turns. ${ }^{29}$ Yet one cannot conclude that these are mere musical interludes. The content of the first two reyen is certainly designated to heighten the dramatic tension, throwing into sharp contrast the festive mood of the unknowing citizens and the holiness of Christmas night with the devious plans of the enemy and the preparations for the devastating attack. The Rey van Klaerissen is different in that their lamentation of the massacre of the Innocents not only comments on the slaughter of Amsterdam citizens that occurs simultaneously but also foreshadows their own martyrdom. Besides, after this Rey the nuns become directly involved in the action onstage together with Bishop Willebrord and Abbess Klaeris van Velzen. They even sing another song (1l. 1007-18), but this time at the behest of the bishop and - although taking up the theme of preparing for death - their singing is now embedded within the action, as is also attested by Gijsbreght's commenting on it (1. 1019).

The fourth Rey is different to the previous ones; sung by burghzaten ('denizens of the castle'), it is likely that these are already present onstage at the preceding conversation between Badeloch and Arend. At any rate, they are clearly aware of the situation and are commenting directly on it, describing Badeloch's anxiety and praying with her for the return of her husband. Their involvement in the action is also clear from the fact that - contrary to the three other reyen - this one does not conclude the act proper. That is done by Badeloch, who hears

\footnotetext{
${ }^{28}$ On the functions that choruses can have in early seventeenth-century Dutch tragedy, see Van Gemert, Tussen de bedrijven door?, esp. pp. 48-94.

${ }^{29}$ For a general discussion of music on the Amsterdam stage in the seventeenth century see: Veldhorst, De perfecte verleiding, pp. 14-64. Specific references to music in Vondel's plays, including Gysbreght, can be found in Grijp, 'Theatermuziek uit de Gouden Eeuw', http://www.camerata-trajectina.nl/display.php?l=nl\&i=toelichtingen \#theater.
} 
Gijsbreght's voice at the gate (11. 1287-88). Nevertheless, just like the other reyen, this one also retains a certain aloofness, by using extended metaphors and by commenting (as it were) 'from the outside', causing epic distancing - an effect that was no doubt enhanced by the singing. ${ }^{30}$ It is precisely this 'distancing' feature of the reyen that should be reckoned with when performing Gysbreght. It can be realised in a multitude of ways, one of them being, of course, actual distancing in the mise en scène whereby the performers are spatially separated from the rest of the action. But to conclude therefore, as Albach does ${ }^{31}$ that all reyen in the first production were probably sung on the balconies of the stage building is a rather farfetched assumption that might be paying too little consideration to the involvement from the reyen on the level of the dramatic action - especially from the latter two.

\section{Costumes and Props}

The implicit indications for the characters' appearance, what they wear and what props they use are somewhat more extensive than those for places and times. Supposedly the characters that belong to certain religious or military groups and that are recognisable by their clothing such as Carthusian monks, Klaerissen or soldiers from both sides - will have been dressed accordingly. But there is also quite a wealth of detailed clues for some of the single characters. Vosmeer is shackled (1. 347) and - probably - covered in mud (1.301); later on he is wet and his teeth are chattering from the cold (1. 609). Badeloch appears in a fine and stately dress for Christmas night ('my Christmas gown and finery', 'mijn pronck en Kersnachts kleren', 1. 745) and Gijsbreght, when going into battle, orders his servants to bring his helmet, armour and sword $(11.851,883)$. Likewise the dying Arend wears armour (Gijsbreght specifically mentions this and orders it to be removed from the body, 11 . $1542,1550)$ and it is quite safe to assume that in addition to this the other characters involved in the skirmishes will have worn battle dress and weaponry of some kind. The messenger probably enters with the armour, sword and plumed helmet he has taken from a dead enemy to disguise himself. Most extensively Vondel's text details how onstage

\footnotetext{
${ }^{30}$ In later productions the reyen were often not sung but spoken in unison by groups of actors in a bombastic and declamatory style.

${ }^{31}$ Albach, Drie eeuwen 'Gijsbreght van Aemstel', p. 19.
} 
bishop Gozewijn is helped into his finest chasuble and is handed his full Episcopal regalia - mitre, golden ring and crosier:

But dress me first, before they swoop down upon us.

Adorn this feeble body with most precious copes

Appropriate for a Bishop, lest I die in shame.

Crown me with the mitre: I've always worn it well

On my anointed head. Then bring the golden ring.

Put on this finger - my hand trembles - the wedding-band

[...] Then hand me the shepherd's crook, [... ${ }^{32}$

Apart from the text there is also ample evidence from the ledger of the Schouwburg that quite some money was spent on the costumes and props for the extensive cast. One finds entries for payments to an armourer and to a swordsmith, for feathers, bows, gloves and jewellery, for boots, and for linen used to clothe the nuns and monks, for velvet, for silk and even for the wings of a swan - the latter undoubtedly having served for Raphael's costume. ${ }^{33}$ So apparently the actors' attire merited a lot of attention and this is corroborated by Rembrandt's drawings of the Gysbreght characters with their elaborate clothing. However, none of this means that the costumes were historically correct. Albach supposes that the clothes were in essence seventeenth-century garments - ostentatious dresses for the women and parade armour with feathered helmets for the men ${ }^{34}$ - and this might have helped a contemporary audience to identify with the characters, but at the same time it seems probable from Rembrandt's sketches that the clothing certainly was not ordinary and within the conventions of the time will have been recognised as 'historical'. So again one sees that in 1638 , just as with the virtual configuration of the 'historical' Amsterdam, the costumes probably presented an amalgam of old and contemporary features. And one should further conclude that, although from a textual perspective dressing the characters in a certain way and giving them certain props cannot be avoided, the range of design and appearance is much greater than the indications might seem to suggest.

\footnotetext{
32 Vondel, Gysbreght, 11. 989-94: 'Maar treck me (dat mijn dood zy veer van schande en smaed) eerst aan dit lamme lijf mijn prachtighste gewaad, gelijck een Bisschop voeght, aleer zij ons verrasschen. Zet mij den mijter op: hy zal niet qualijck passen Op mijn gezalfde kruin. breng hier den gouden rings, En steeck aen deze hand, die beeft, den vingerling $[\ldots .$.$] Geef mij den harderstaf [...].'$

${ }^{33}$ Albach, Drie eeuwen 'Gijsbreght van Aemstel', pp. 135-38. Also: Smits-Veldt, '3 januari 1638. Opening van de Amsterdamse Schouwburg met Vondels Gysbreght van Aemstel', pp. 206-07.

${ }_{34}$ Albach, Drie eeuwen 'Gijsbreght van Aemstel', p. 21.
} 


\section{The Angel Raphael}

A particular problem with regard to staging and costuming is presented by the angel Raphael who appears as a deus ex machina at the end of the play. There can be little doubt that in Vondel's time this celestial being was presented in accordance with the conventional image that we encounter at large in the pictorial tradition: a youngster in white (?) robes with wings. One can also be sure that Raphael made his entrance from the 'heavens' (above the central compartment of the stage building) in a cloud that then descended to the ground level of the stage. This machinery was one of the technical features of the new Schouwburg that the management certainly would have liked to show to the curious audience. In modern times, of course, it would also be possible to call on all sorts of technical devices to stage a grand finale with a winged angel descending from above. However, the question is whether this would work as an acceptable end to the drama. Not only is it likely that today's audiences will have more problems than the spectators in Vondel's time with the divine intervention as such (and of course this cannot be helped: it is a structural given of the play), but also the appearance of the angel itself can be seen as a challenge that should not necessarily be tackled by reverting to the traditional depiction with wings. It is therefore no surprise that different solutions have been tried in this regard, including not showing the angel but presenting only a voice - one of the more popular options. Whatever approach a theatre maker adopts it should be remarked here that in Vondel's text the angel is not a private figment of Gijsbreght's imagination, but is perceived by all the characters onstage. The words of Broer Peter 'Who was that? Raphael?' ('Zijt ghy dat Rafaël', l. 1865) - make this unequivocally clear. ${ }^{35}$

Our explorations up to this point have indicated some problems and challenges inherent to any staging of Gysbreght but they do not seem to be insurmountable. Indeed, the very vagueness of a lot of the features that were discussed presents the possibility of staging the drama in a large variety of ways and can be seen as one of the reasons that the tra-

${ }^{35}$ This observation is also important because it throws some light on the interpretation of both Badeloch's dream and Gijsbreght's account of how he was led to the nunnery of the Klaerissen after having heard a divine voice and having been led by a holy light. Apparently both these admonitions to save the nuns and the bishop should be considered more or less 'false' visions insofar as it was obviously not the intention to save Gijsbreght's uncle and sister. Cf. Raphael's lines (ll. 1825-26): '[...] hadden wy't in ons behoed genomen / 't En waer met Amsterdam zoo verre noit gekomen.' 
dition was able to survive the many changes in production habits for well over three hundred years. And according to this analysis nothing seems to stand in the way of a modern staging. Should one conclude, then, that the verdict 'unplayable' for modern-day theatre makers has in reality little to do with the technical or structural demands of the drama, but is rather referring to matters of content, theme and unintelligible language? To begin answering this question one has to look at the more structural aspects of the play concerning the relationships of story and plot and of action onstage and offstage.

\section{Theatricality of Gysbreght}

In theatre, the action and characters are shown rather than described. The spectator perceives the events and does not have to conjure them up in the mind's eye from a spoken or written text. It is this principle - known as ostension - that functions as one of the major characteristics in distinguishing theatrical performance from other art forms especially literary ones - and it is also recognised as the leading principle that underlies the specific form and structure of a drama text. Such a text distinguishes itself from the literary story by the relative invisibility of a narrating instance and by mainly consisting of direct speech. ${ }^{36}$

To give just one, rather normative example of this narratological reasoning on how stories are told in the theatre, I will cite a certain Hasselbach, who wrote in his Overzicht der Stijlleer ('Overview of Stylistics') as early as 1890 :

Drama too creates an image of life - just as the epic poem and the novel do - but here the events should not be narrated, they must be shown. [...] A drama - the word itself meaning action - should therefore consist of a sequence of important events that quickly, without unnecessary delay, develop before the eyes of the audience. [...] It follows that the main requirements for drama are action and delineation of character. But stories and lyrical utterances are not completely banned from the drama; they can even clarify or embellish the [dramatic] poem, provided that the playwright takes care that they do not take up too much room and are fittingly embedded at just the right moment in time. ${ }^{37}$

${ }^{36}$ Cf. for example Pfister, The Theory and Analysis of Drama, transl. Halliday, chapters 1 and 2 .

${ }^{37}$ Hasselbach, Overzicht der Stijlleer, pp. 45-46: 'Evenals het epos en de roman vormt ook het drama een beeld van het leven, doch hier mogen de gebeurtenissen niet 
Yet the emphasis on the showing of action that is expressed in this citation is somewhat biased and is not altogether confirmed by theatrical practice. There are specific moments when, onstage, stories are told instead of shown and when, moreover, one should not designate these stories as 'clarification' or 'embellishment' but rather deem them to be quite important - if not crucial - in furthering the action and developing the plot. These are the moments when characters relate in words parts of the action that remain invisible to the audience and to the other characters.

Confronting the above with Gysbreght one realises immediately how much this play relies on narration to present the story and not on any action shown onstage. In the Kort Begrijp that precedes the drama text Vondel describes the course of events that make up the action of the play and that can best be summarised by its motto, taken from Virgil's Aeneid: 'urbs antiqua ruit' ('the old city perishes'). The taking of Amsterdam on Christmas night, its destruction and the subsequent exile from the city of Gijsbreght, his family and the refugees are related in chronological order, but no distinction is made between what is shown onstage and what is narrated. In the analysis of the manner in which this story is staged - the plot - one learns, however, that very little of the events can actually be seen directly by the audience; almost everything pertaining to the hostilities is reported and has to be perceived through the narration by the characters.

Table 2 indicates the number of verses from each scene, the characters that are definitely onstage and a short description of its main content. In these descriptions it is also indicated whether this content actually shows events from the main story or is relating these events through narration. In more technical terms it is indicated whether in a scene the events related by the plot coincide with those of the story or whether they have happened before and offstage, outside the direct perception of the audience. The former are designated by Action or Conflict - all the other descriptions are essentially characterised by narration, leaving it to the spectators to conjure up before their minds eye

worden verhaald, ze moeten vertoond worden. [...] Een drama - 't woord zelf beteekent handeling - behoort dus te bestaan uit eene reeks van belangrijke feiten, die zich ras, zonder onnoodig oponthoud, voor de ogen der aanschouwers ontrolt. [...] De hoofdvereischten van het drama zijn dus handeling en karakterschildering. Evenwel verhalen en lyrische ontboezemingen zijn niet geheel en al uitgesloten; ze kunnen het gedicht zelfs verduidelijken en versieren, mits de dichter zorg drage, dat ze eene niet te groote plaats innemen en juist te pas zijn ingevlochten.' My translation. 
what has actually happened. A special case of the Action scenes is provided by those marked Conflict. In these scenes the actions onstage are characterised by clearly opposed objectives of the characters: Diedrick meeting resistance when he wants to gain access to the Carthusian monastery; the refusal of the Klaerissen and Gozewijn to be led to safety by Gijsbreght; the Heer van Vooren trying in vain to negotiate the surrender of the castle; and Badeloch's refusal to obey Gijsbreght's orders to flee the castle. In a sense these scenes can be considered to be even more theatrical than the other ones in which the action dominates the narration but in which the characters comply with each other. ${ }^{38}$

From the table it is now possible to estimate more or less accurately how much of Gysbreght is devoted to direct action and how much the play relies on narrative. The scenes actually showing parts of the military action itself or presenting a conflict between the characters present onstage take up only about $50 \%$ of the drama: 957 of the 1896 verses. And it should even be recognised that sometimes large parts of these action scenes still contain long passages that can be regarded as predominantly narrative: for example, Vosmeer's account of his past, Badeloch telling her nightmare and Raphael prophesying the future. So the actual number of lines that should be considered narration instead of action is even considerably higher; the vast majority of the play actually consisting of stories and reports about what has happened in the past, what is happening offstage and what will happen in the future.

In this sense Gysbreght should definitely be considered more of a literary play than a theatrical one and it would not be much of an exaggeration to say that the drama does in fact comprise only a series of messenger reports. The consequence of this is, of course, that the audience becomes somewhat removed from the events, focussing on them through the interpretations and reactions of the characters, but not experiencing these events themselves. This distancing effect might even be furthered by the fact that the events are not told in everyday language, but rather in elaborate, rhythmic and poetic verses - thereby possibly strengthening the awareness of dealing with aesthetic constructions rather than with realistic characters. On the other hand the

\footnotetext{
${ }^{38}$ The view that conflict is an essential element of drama is presented by various aurhors. Cf. for example Pfister, The Theory and Analysis of Drama (tr. Halliday), pp. 196-201 or Beckermann, Dynamics of drama:theory and method of analysis, passim.
} 


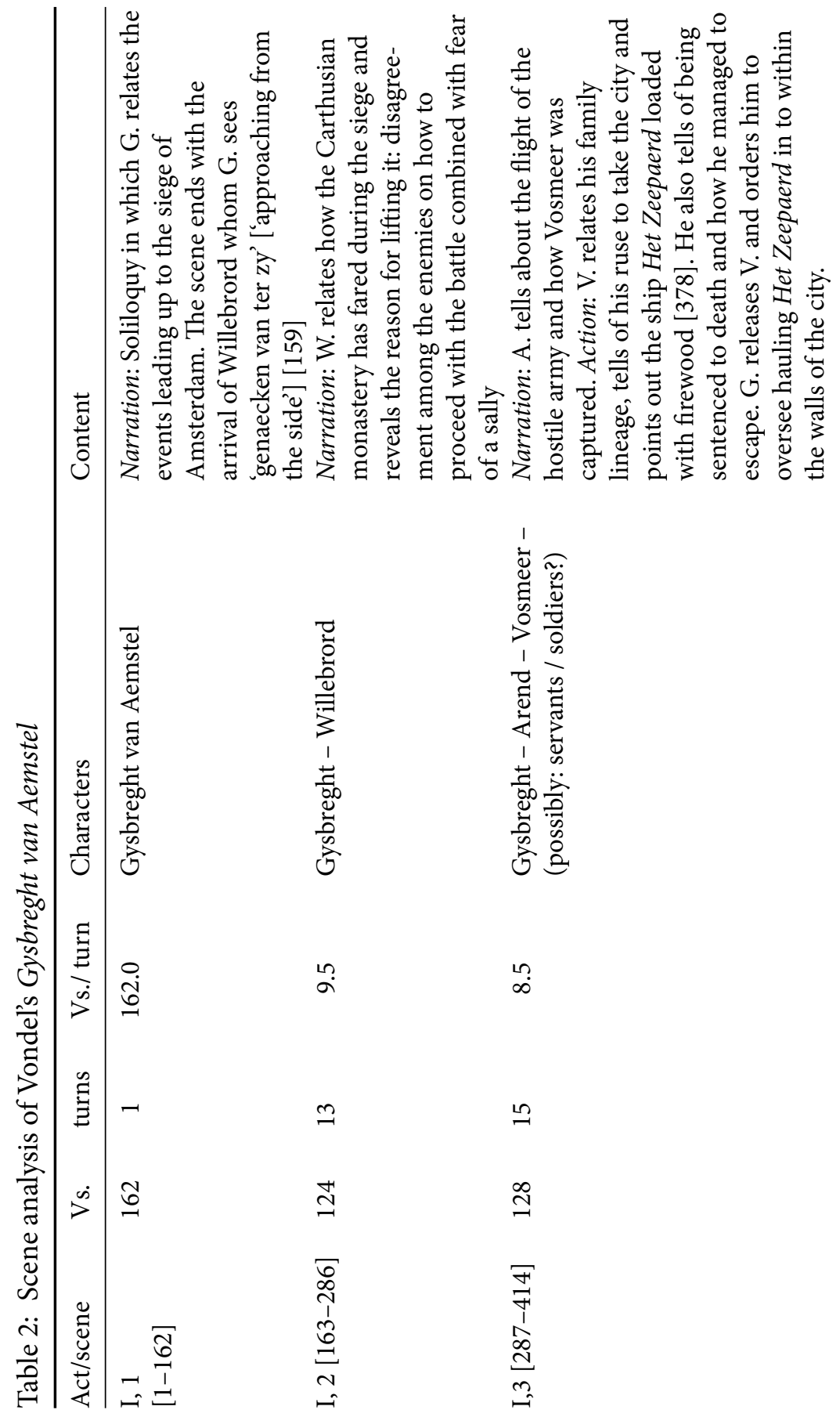




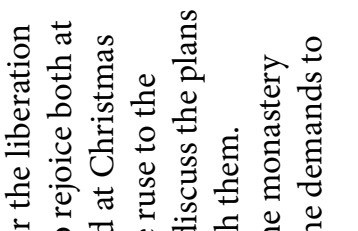

s.

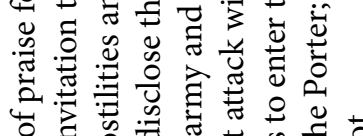

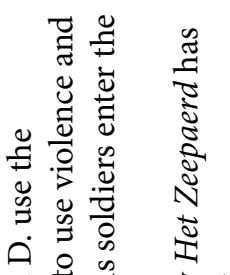

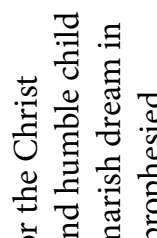

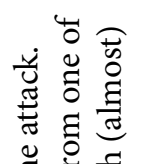

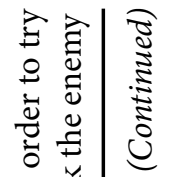

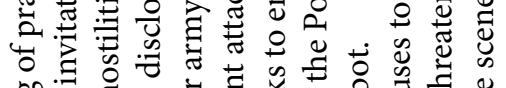

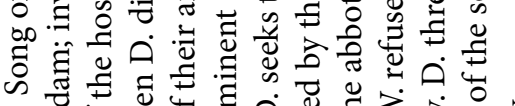

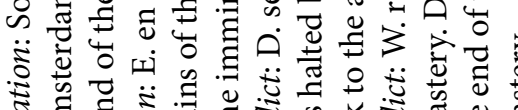

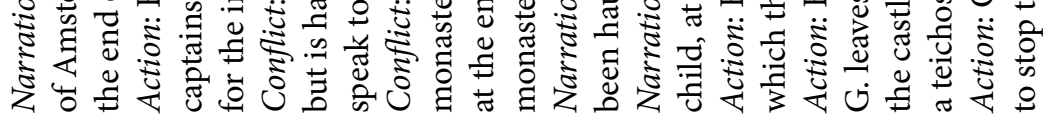

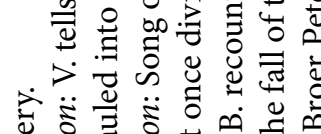

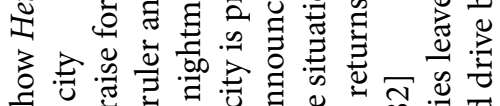

पi

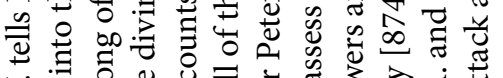
$>-\overline{0}$ 论

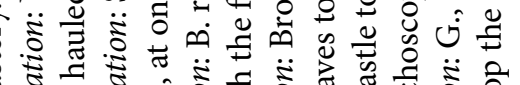

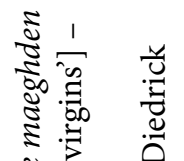

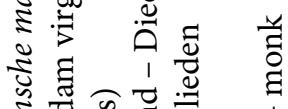

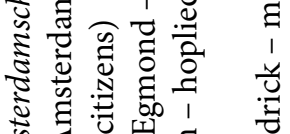

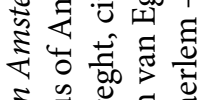

ई

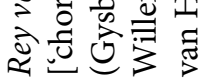

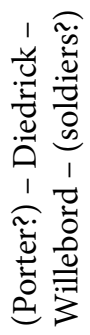

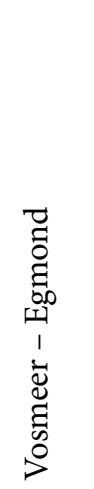

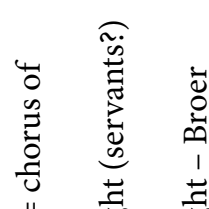

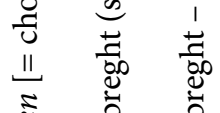

党

离

空芯

ई $\frac{\pi}{2} \frac{0}{0}$

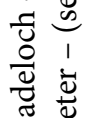

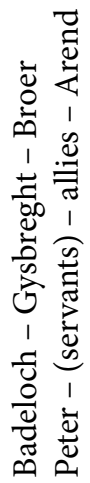

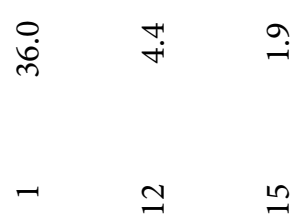

$\ddot{r}$

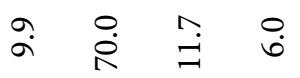

$\stackrel{\circ}{i}$

in

m n $\stackrel{\infty}{\pi}$

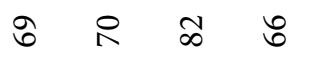

으

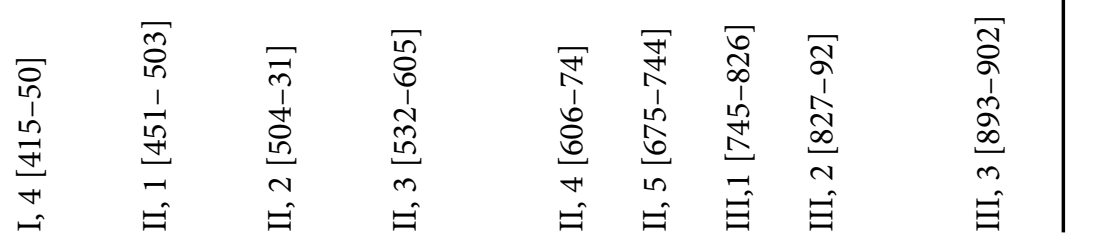




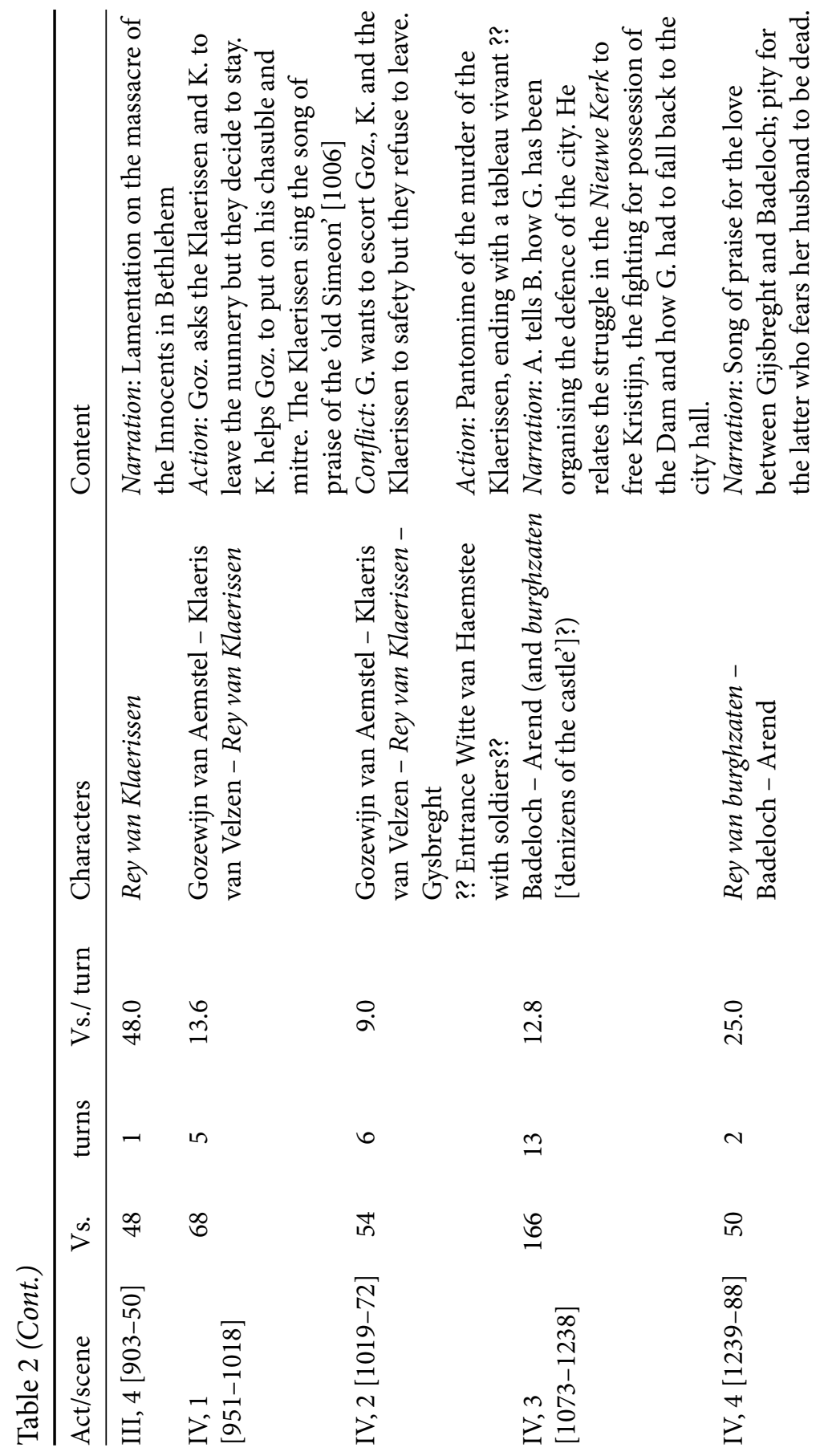




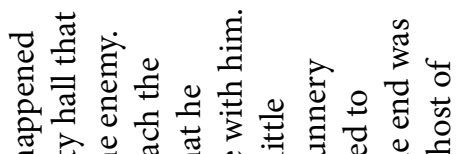

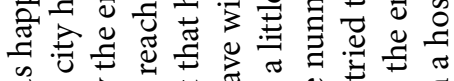

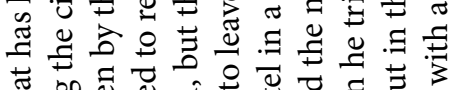
可

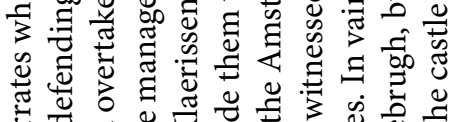

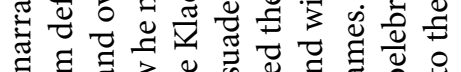

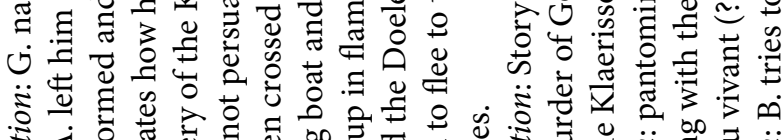

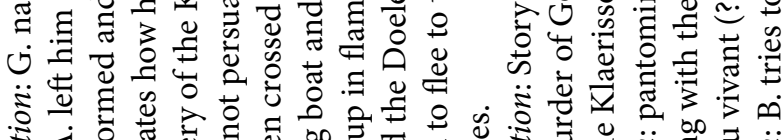

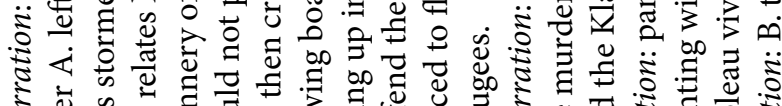

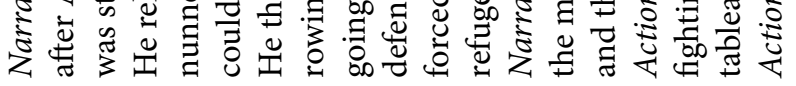
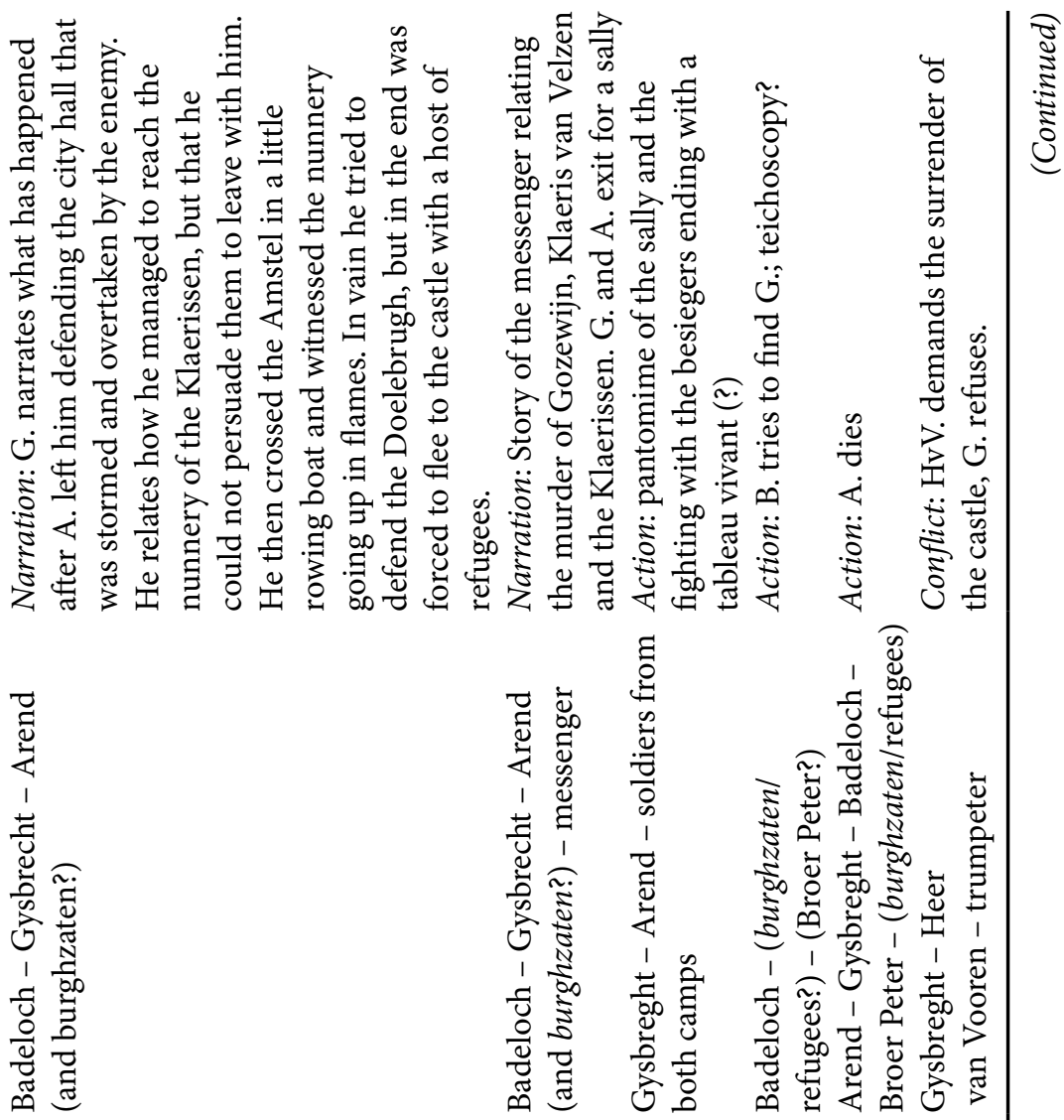

$\stackrel{\infty}{\text { ஸे }}$

$\stackrel{\text { Nִ }}{ \pm}$

$\stackrel{ }{\stackrel{ }{テ}}$

in

a

$-\exists \approx$

오

$\stackrel{\infty}{\sim}$

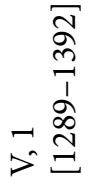

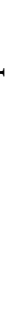

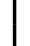




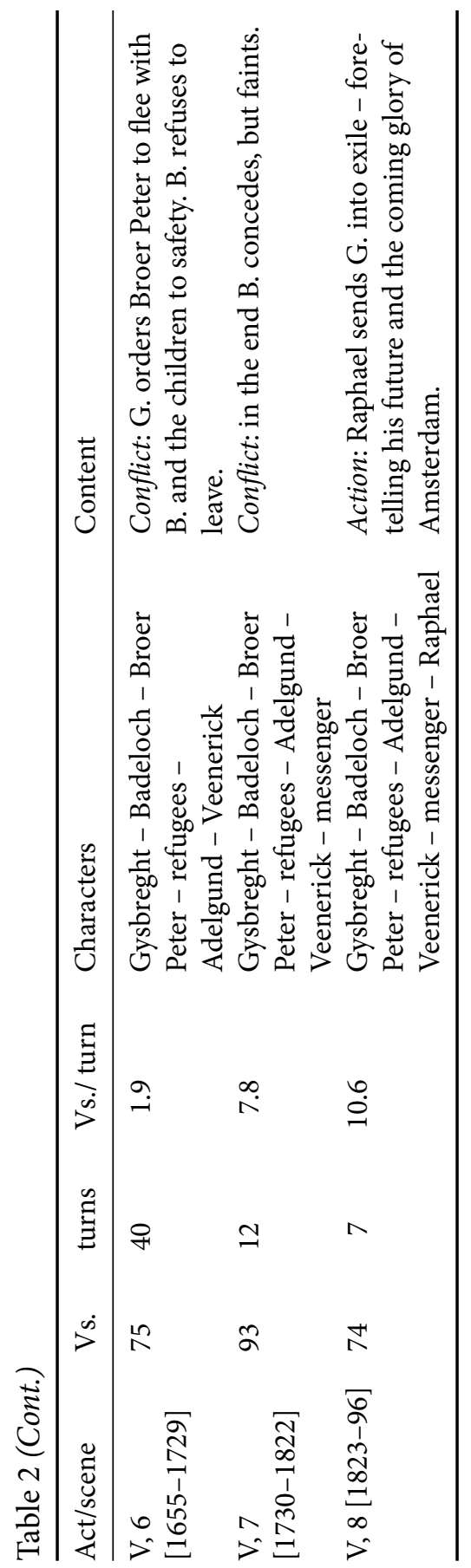


stories make an appeal to the audience to imagine things for themselves and as such they might well be more effective than a cumbersome staging of the events. The suggestive accounts of the battle and the atrocities - such as the murder of the nuns - could very well be more haunting than a meticulous enactment of the events themselves. Besides, from a producer's point of view it is much more efficient to employ a narrator than have to stage a whole battle. Obviously it is much easier to sketch in words how the Zeepaerd was hauled into Amsterdam or how Gysbreght tried in vain to defend the city hall than to present these events on a stage. And telling the story instead of showing it has the additional advantage that one need not worry about good or bad seats: the theatregoers in the back rows can enjoy the terrors just as much as those in the front and the narrative can focus on details that otherwise might be lost. Therefore these evocative accounts of bloody battles and unimaginable horrors form quite a challenge to the actors who have to draw in the spectators, stirring their imagination and invoking the necessary pity and fear by the powers of their declamatory skills. No wonder then that the role of the messenger in the Gysbreght was much sought after and has been enacted by the most famous actors. ${ }^{39}$

Nevertheless, bearing in mind Hasselbach's requirements for good drama and his admonition to the playwright that stories and lyrical utterances should not take up too much room, one must confess that having more than half of the verses in Gysbreght devoted to them is rather a lot. It is therefore not too hard to understand or even sympathise with those critics who have found the play tedious and boring such as the nineteenth-century author Busken Huet who criticised the drama fiercely and remarked that 'Gysbreght van Aemstel is a tragedy at the performance of which [...] everybody longs to get home.4 ${ }^{40}$ Maybe, then, it is this dominance of narrative scenes over action-driven ones that causes the drama to be thought of as unplayable for modernday audiences. After all, today's spectator lives in an era where cameras are ubiquitous, where the importance of pictures seems to be evergrowing and where the means of communication make it possible to

${ }^{39}$ Cf. Albach, Drie eeuwen 'Gijsbreght van Aemstel', p. 9 and Prandoni, Een mozaïek van stemmen, p.13.

${ }^{40}$ Cf. Gemert, '3 januari 1638: De opening van de Amsterdamse Schouwburg' pp. 232-33 and Prandoni, Een mozaïek van stemmen, p.18. The latter gives the quote from Busken Huet: 'Gysbreght van Aemstel [is] een treurspel bij welks opvoering niemand treurt en de geheele wereld naar huis verlangt.' 
witness events and their outcomes as they happen and with one's own eyes. As such it should therefore not be very surprising that nowadays in the theatre descriptive messenger stories after the fact, however eloquently worded, will be experienced as less exciting than the 'real' stuff: directly showing the actions and the characters in conflict with each other.

The narrative overload of the drama and its consequences become even more apparent when one calculates the average number of verses per speaking turn in each scene. Figure 1 provides a graphic representation that also takes into account the (approximate) length of the scene. The figure can be considered a rough blueprint of the overall 'rhythm' of the play, indicating the relative pace of each scene. The lower the bars are the more lively the play tends to become: either because the scene itself is very short and takes up only a few lines or because there is a multitude of dialogical turns between the characters. Conversely, longer bars mean relatively less turns and the drama will tend to have a slower tempo and become more monotonous.

The figure readily demonstrates the lengthy exposition of Gijsbreght's prologue $(I, 1)$ and the four reyen that function as resting points between the acts $\left(\mathrm{I}, 4 ; \mathrm{II}, 5 ; \mathrm{III}, 4\right.$ and IV,4). ${ }^{41}$

It also becomes clear where the pace of the drama really quickens and one can find the more weighty moments of the action and especially of conflicts between the characters onstage. In chronological order these are:

- the beginning of the second act where Vosmeer's ruse is revealed by Diedrick and Egmont to their captains and the subsequent quarrel to gain access to the Carthusian monastery (II,1; II,2; II,3 - 155 verses)

- The news of the attack by Broer Peter; Gijsbreght rallying the allies and leaving for battle (III,2; III,3 - 76 verses)

- The fifth act after the story of the messenger till the appearance of the angel: Badeloch seeking Gijsbreght, his return with Arend who dies, the conflictual negotiation with De Heer van Vooren and the quarrel between Gijsbreght and Badeloch who refuses to part from the castle $(\mathrm{V}, 3 ; \mathrm{V}, 4 ; \mathrm{V}, 5 ; \mathrm{V}, 6 ; \mathrm{V}, 7-302$ verses)

${ }^{41}$ For the sake of clarity of the whole figure the actual average number of verses per speaking turn of these five scenes is not represented by the length of the bars: they are cut off at 25 . 


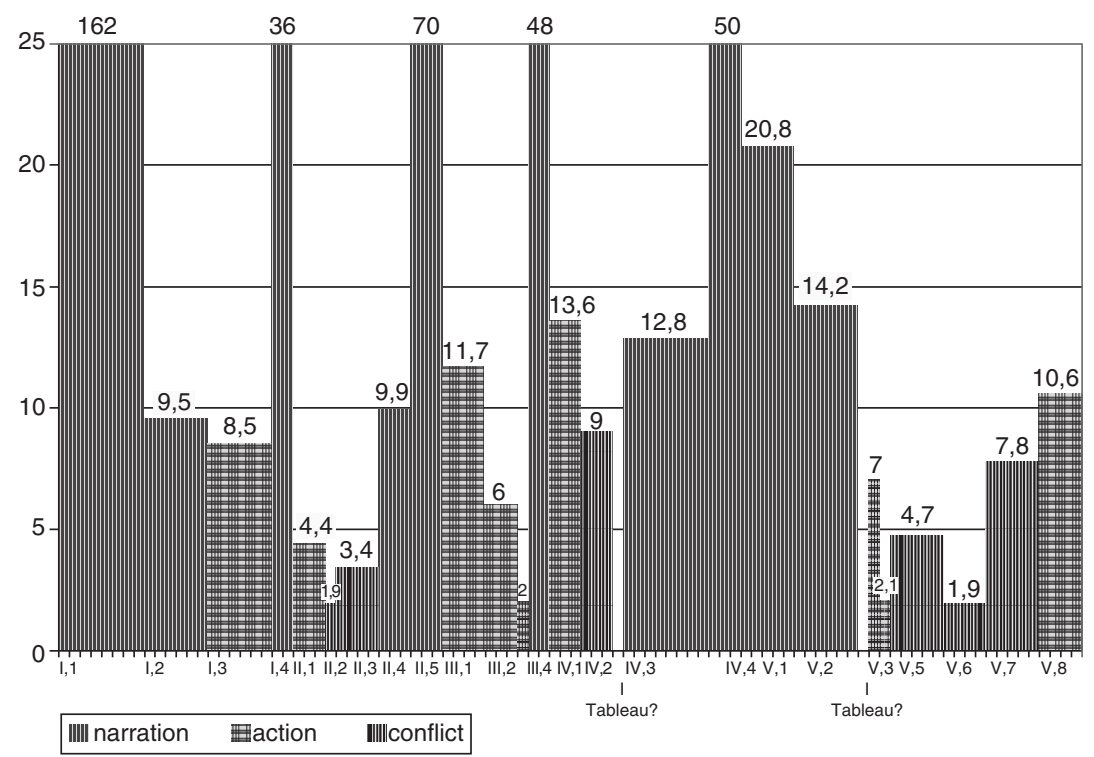

Average lines per speaking turn.

All the other scenes - even the ones depicting actions directly connected to the battle (such as Gijsbreght trying in vain to persuade bishop Gozewijn and the Klaerissen to flee with him) - have a markedly slower tempo. This holds especially true for the relatively long tales by Arend, Gijsbreght and the messenger who relate the progress of the battle only to be interrupted by an occasional exclamation or short question from the party being addressed (VI,3; V,1; V,2). So one should conclude that the analysis of the overall tempo of the play corroborates the findings with regard to the large amount of narration in the play. Only in a few instances does the rather slow rhythm really pick up and strong (discordant) interaction between the characters or a sudden turn of events find expression. These are relatively short scenes, however, and the majority of them occur in Act V, so the spectator bent on seeing fast-paced action and quarrelsome dialogue has to wait quite a while before his appetite is finally sated.

\section{Tableaux Vivants and Pantomimes}

With this dramatic structure, which is characterised by a clear dominance of staged narrative and a rather drawn-out rhythm it is 
unsurprising that theatre makers have more than once tried to enliven the drama; either by cutting considerable parts of the text or by providing the spectators with things to look at rather than to listen to. The elaborate costumes of the first performances have already been discussed and, although up till now we have only focussed on the characters that are mentioned in the text as being absolutely necessary for each scene, there is ample evidence from the Gysbreght tradition that, in addition to the main characters, a large number of supernumeraries have often been employed. Indeed, having a lot of actors onstage enhances the possibilities for the visual layer of a performance and the deliverance of large fragments of narrative can benefit from it - both with regard to mise en scène and with regard to the range of the story's emotional impact that can be shown. And, of course, one can also try to visualise the stories, thereby providing the audience with images of the spectacles that otherwise are only conjured up in words. Famous devices that have frequently been deployed to do this and that have been especially important in the performance history of Gysbreght are the pantomime and the tableau vivant. Indisputable evidence for the production of 1638 is lacking but it has been surmised that already at that time the taking of the Carthusian monastery, the murder of the nuns and Gijsbreght's sally from the castle were actually enacted as pantomimed skirmishes. ${ }^{42}$ Furthermore, it is well documented that tableaux vivants were very popular at the time and one or two of them might well have been inserted into the performance. At any rate, there is a lot of visual and documentary evidence from the 18th century and onwards to the effect that a tableau vivant showing the murder of the Klaerissen was an indissoluble and often much-praised part of the performances. In a report by Louis Riccoboni one learns how this was done in 1738:

Another peculiarity of the old theatre is what they call Vertoning (tableau vivant): they lower the curtain in the middle of an act, and arrange the actors on the stage in order to represent, in the manner of the pantomime, some main action of the play's contents. Thus in Gysbreght van Aemstel they raise the curtain, \&the theatre shows the soldiers of Egmont, Gijsbreght's enemy, who plunder a nunnery; each soldier takes hold of a nun and treats her as it pleases him. The Abbess lies down in the middle

${ }^{42}$ Albach, Drie eeuwen 'Gijsbreght van Aemstel', p. 20 and Smits-Veldt, ' 3 januari 1638. Opening van de Amsterdamse Schouwburg met Vondel's Gysbreght van Aemstel.' p. 205. Also Prandoni, Een mozaïek van stemmen. p. 107. 
of the stage, holding on her knees the venerable Goswin, the banned bishop of Utrecht, who is then slaughtered in his pontifical clothes, the mitre on his head and the cross his hand. ${ }^{43}$

And Pierre Coste d'Arnobat is even more precise in his description dating from the end of the 18th century in which attention is also given to the emotional impact of the scene:

All of a sudden [...] an enemy chief, followed by his soldiers, forces his way into the convent. The sacrilegious troop bursts into the choir, slitting the throats of the bishop and the nuns, and desecration fills the sacred place. In order to preserve the effect of every detail of this coup de théâtre, in order to be able to guess at the same time, among such horrors, all those details that, due to the constraints of decency, cannot be shown in live action, the curtain is lowered when the action is rapid and chaotic; and it is raised the very next instant, in order to display the assassins and the victims scattered in various poses of fury and horror, also giving some indications of the soldier's licentiousness. On witnessing this huge, symmetrical pile of corpses and executioners, and how the scene is displayed in the utmost silence, the emotions of the Dutch are expressed in redoubled applause, and everyone seems to be completely overwhelmed by this beautiful, dramatic-tic [sic] image. ${ }^{44}$

${ }^{43}$ As translated by Hogendoorn, 'Dutch Theatre, 1600-1848', p. 421. Original by Louis Riccoboni, Reflexions historiques et critiques sur les differens théatres de l'Europe, p. 145: 'Une autre singularité de l'ancien Théatre, est ce qu'on nomme Vertoning (Répresentation): on baisse le rideau au milieu d'un Acte, \& on dispose les Acteurs sur le Théatre, de manière représentent, comme à la façon des Pantomimes, quelque action principale du sujet. C'est ainsi que dans Gysbrecht van Aemstel, on léve le rideau, \& le Théatre représente les Soldats d'Egmond ennemi de Gysbrecht, fui faccagent un Couvent de Religieuses, où chaque Soldat en a une qu'il traite comme il veut: l'Abesse est étendue au milieu du Théâtre, tenant sur ses genoux le vénérable Goswin, Evêque exilé d'Utrecht, massacré dans ses habits Pontificaux, la mître en tête \& la crosse à la main.'

${ }_{44}$ Pierre Coste d'Arnobat as reproduced in Albach, Drie eeuwen 'Gijsbreght van Aemstel', p. 139: 'Tout à coup, ... un chef ennemi, suivi de ses soldats force le couvent. La troupe sacrilege fait irruption dans le coeur, elle égorge lévêque et les religieuses, et la profanation est dans le lieu saint. Pour que l'effet d'aucun détail de ce coup de théâtre ne soit perdu; pourqu'on puisse deviner à la fois, parmi tant d'horreurs, toutes celles don't la décence ne permet pas d'exposer le tableau mouvant, on baisse la toile au moment où il sopère à grands traits et en confusion; et on la releve l'instant après, afin de déployer aux spectateurs les assasins et les victimes grouppés pêle-mêle dans diverses attitudes du fureur et d'épouvante, qui laissent entrevoir aussi quelques indices de la licence du soldat. Au spectacle de ce grouppe énorme amoncelé symétriquement de morts et de bourreaux, et que la scene étale dans le plus grand silence, les transports des Hollandais se manifestent par des applaudissemens redoublés, et tout le monde paroît pénétré de cette belle image dramatiq-tique [sic].' Cf. also Is. Disraeli (Curiosities of Literature, 1820; but written at the end of the 18th century) as reproduced in Albach, Drie eeuwen 'Gijsbreght van Aemstel', p. 140: 'One of the acts concludes with the scene of a convent; the sound of warlike instruments is heard; the abbey is stormed; the nuns 
From this latter quote it becomes clear how one should imagine this scene and the relation between pantomime and tableau: Witte van Haemstee and his soldiers enter the stage just after Gijsbreght has left and there is some struggling with the nuns. However, for reasons of decency all the atrocities as later told by the messenger (such as Klaeris van Velzen being raped) are not shown, but at some culminating point the curtain is lowered and almost immediately raised again to show the outcome of the slaughter. ${ }^{45}$

\section{Conclusion}

Having thus explored some of the possibilities of Gysbreght for its staging we can now return once more to our initial questions - from the point of view of a theatre maker, what are the structural characteristics and the technical demands of this text that might explain both the very long, almost unbroken tradition of yearly performances from 1638 onwards and the ultimate cessation of that same tradition in 1968 ? With regard to the former it should be remarked that the immanent clues for spatial and temporal configuration, for costumes and props, for mise en scène and the delivery of the reyen are quite indeterminate. They leave a lot of room for different interpretations and can be accommodated by various and even opposed theatrical conventions. Realistic or stylised, on a monotopic or polytopic stage, in elaborate settings or on an almost bare stage, with choruses sung or spoken - Gysbreght is vague enough in its indications to conform to them all. The question as to the cessation of the tradition and why it has not been revived is somewhat harder to answer. I suspect that it has to do not only with the content of the play or the difficulties in understanding the seventeenthcentury language and the direct references to the historical situation but also with structural characteristics of the play. The tragedy relies heavily on telling the story instead of showing it, resulting in a relatively slow and monotonous overall rhythm. In a time where visuality

and fathers are slaughtered; with the aid of 'blunderbus and thunder' every Dutchman appears sensible of the pathos of the poet. But it does not here conclude. After this terrible slaughter, the conquerors and the vanquished remain for ten minutes on the stage, silent and motionless, in the attitudes in which the groups happened to fall! and this pantomime pathos commands loud bursts of applause.'

${ }^{45}$ In this respect it is important to note that the messenger story in act $\mathrm{V}$ is not recounting exactly what the audience has already seen but gives additional information on the gruesome events. Cf. also Prandoni, Een mozaïek van stemmen, p. 105. 
and spectacle are regarded highly, where images are ubiquitous and often considered more trustworthy than just words, it is only natural that staging a drama in which many of the main events of the story are told and which has only a limited number of scenes in which something happens in terms of action or conflict is not so much en vogue. And yet... reading Vondel's verses with their almost magical power to conjure up so vividly the attack on Amsterdam and its subsequent destruction one wonders how a present-day theatre production might be able to overcome these inherent challenges presented by Gysbreght. 